\title{
The Geography of Air Freight: Connections to U.S. Metropolitan Economies
}

By: Khaula A. Alkaabi and Keith G. Debbage

Alkaabi, K. A. and K. G. Debbage. (2011). "The Geography of Air Freight: Connections to U.S. Metropolitan Economies” Journal of Transport Geography, 19(6) 1517-1529

Made available courtesy of Elsevier:

http://www.sciencedirect.com/science/article/pii/S0966692311000457

***Reprinted with permission. No further reproduction is authorized without written permission from Elsevier. This version of the document is not the version of record. Figures and/or pictures may be missing from this format of the document. $* * *$

\begin{abstract}
:
Despite the rapid growth of air freight shipments, much of the existing literature on the geography of air transportation has paid more attention to passenger travel than air freight. The purpose of this paper is to elevate our understanding of air freight by determining which specific variables most influence and shape the geographic distribution of air freight by metropolitan area using stepwise regression analysis. The empirical results suggest a regression model of five independent variables was the most parsimonious solution where the final model accounted for $71.1 \%$ of the variation in air freight shipments by metropolitan area (MA). The most important predictor was the traffic shadow effect, where less populated MAs under the traffic shadow of larger MAs tended to generate lower levels of freight. The model also suggested that other key predictors included the employment market share in transportation-shipping-logistics industries, per capita personal income, the number of medical diagnostic and supplier establishments, and above average wages in high technology. Overall, metropolitan markets with diverse and efficient ground support systems, freight forwarders and other transportation services, a more affluent population, an intense agglomeration of medical laboratories and related suppliers, and a well paid skilled workforce engaged in computer systems design and electronic product manufacturing are more likely to ship freight by air.
\end{abstract}

Keywords: air freight | traffic shadow effect | transportation shipping logistics | metropolitan economies | per capita personal income | hubs | transport geography

\section{Article:}

1. Introduction

Air cargo is now an essential element in worldwide commerce accounting for about $30 \%$ of U.S. sales shipped overseas. More specifically, Leinbach (2004) has suggested: 
Domestic freight volumes are expected to grow by more than 65\%, increasing from 13.5 billion tons in 1998 to 22.5 billion tons in 2020. Domestic air cargo tonnage is projected to nearly triple over this period, although its share of total tonnage is expected to remain small (p. 35-36).

The commodities that comprise the bulk of air freight shipments include high-value and timesensitive products such as electronic goods, telecommunications equipment, medical and pharmaceutical products, luxury commodities, and photographic equipment (Helms, 1989, Doganis, 1991 and Rodrigue, 2006). The diverse product range means air cargo can play a significant role in meeting a variety of shippers' daily needs (Leinbach, 2004, Moline, 2004, Murphy et al., 1989, Rodrigue, 2006, Rong and Grunow, 2010 and Yamaguchi, 2008). Additionally, Kay (2004) has argued that "an efficient, reliable and economical air cargo industry helps to create jobs, raise income levels, attract foreign investment, promote higher standards of living, and in general, act as an engine for economic development” (p. 5). Because air transportation is the main carrier of rapid, high value - low weight shipments in the United States, developing a better understanding of how air cargo can drive and shape local employment patterns is critical to an enhanced understanding of the economic geography of metropolitan areas. Hesse and Rodrigue (2004) have also argued that economic and transportation geographers need to pay more attention to the economic geography of the logistics, transportation and freight distribution industries if we are to better understand how air freight can shape the geography of metropolitan economies.

The purpose of this paper is to determine which specific factors most influence and shape the geographic distribution of air freight by metropolitan area. It is hypothesized that the geography of air freight is best explained by relative location (or the traffic shadow effect), several key socio-economic variables (e.g., population size, level of educational attainment, per capita income, etc.) and the relative mix of various manufacturing-related activities (e.g., transportation-shipping-logistics, medical diagnostics, high-tech, and pharmaceutical and biotech). Overall, this paper will highlight the crucial role that spatial hierarchy and connectivity play in shaping the economic geography of air freight markets.

\section{Theoretical background and context}

An efficient, reliable air cargo industry can be a significant engine for economic development, but up to now researchers have largely neglected the geography of air freight even though it deserves more consideration and assessment particularly regarding the way in which it might shape and influence metropolitan economies. To date, there has been no comprehensive study of the spatial distribution of air freight. According to some geographers, (Hesse and Rodrigue, 2004 and Rodrigue, 2004, and Vowles 2006), the significant role of freight transportation in the geography of production and consumption by metropolitan area has been largely ignored. That 
said, air transportation has been, and will continue to be, a significant influence in shaping critical geographical concepts such as nodal connectivity, spatial hierarchy and urban agglomeration at a wide variety of different scales (Vowles, 2006). Hesse (2002) has also argued that distribution networks, logistics, and transportation systems can greatly influence economic structural change.

Since the Airline Deregulation Act of 1978, the U.S. air transport system has developed a highly interdependent route network geography where passengers and freight are transported through major hubs, from distant spokes, to their final destinations (Button et al., 1999, Cohen and Paul, 2003, Feighan, 2001, Goetz and Sutton, 1997 and Zhang and Zhang, 2002). More critically, the growth of air passenger transport has been linked to the growth and economic development of different metropolitan areas ( Alkaabi and Debbage, 2007, Brueckner, 2003, Button and Taylor, 2000, Debbage, 1999, Debbage and Delk, 2001, Goetz, 1992, Goetz and Sutton, 1997, Ivy et al., 1995, Mason, 2005, O’Connor, 2003 and Oster et al., 1997). On the other hand, it is not yet fully understood how the geography of air freight transport shapes metropolitan economic performance. Leinbach and Bowen (2004) and Bowen and Leinbach (2004), have examined air cargo services in Southeast Asia, and they argued that the intensity of air cargo services is related to firm structure and operation. They suggested that certain products (like semiconductors) that have a high value-to-weight ratio, fast production cycles and are prone to damage from maritime shipments have all acted to intensify demand for air freight. Green (2007) has suggested that liberalization and improved customs practices have tended to stimulate higher levels of air freight, trade, and economic development (as measured by GDP per capita and foreign direct investment).

What remains less clear is which specific metropolitan areas most benefited from these sorts of interactions. Left unanswered in much of the literature is precisely how U.S. metropolitan economies shape and re-configure the spatial distribution of air freight demand? Are metropolitan areas with a disproportionate share of employment in economic activities like transport logistics, medical diagnostics, high-tech, biotech, and other related industries - all of which tend to ship high-value, low-weight products - generating higher levels of air freight demand? In this sense, this paper is a first step towards a broader-based understanding of how the geography of air freight can be influenced by the geography of metropolitan labor markets 'on the ground'.

A useful overarching conceptual framework for much of this research agenda is provided by Kasarda's (2008) notion of the aerotropolis and airport core city (Fig. 1). The introduction of emarketplaces with the expansion of business-to-business (B2B) supply-chain transactions, and 
the increased demand for networking, speed, and reliability have all played a fundamental role in generating new planned airport-related agglomerations in places like Amsterdam's Schipol Airport or the Dallas-Fort Worth Airport. The concept of the airport city or what Kasarda (2008) has coined 'aerotropolis' is based on the notion that some airports are now shaping business locations and urban development in ways in which highways, rail and seaports did in the past (Al Chalabi and Kasarda, 2004 and Leinbach, 2004). The aerotropolis concept in some ways is the explicitly spatial manifestation of the agglomeration of industries related to time-sensitive manufacturing, e-commerce, telecommunications and third-party logistics firms focused on a central airport node (Kasarda, 2008 and Pinkowski, 2007) (Fig. 1). Better understanding the conceptual underpinnings of the aerotropolis might help us better explain why some metropolitan areas have experienced an intense spatial agglomeration of time-sensitive industries and transportation-shipping-logistics activities around their airports while other metropolitan areas have been less successful.

\section{Figure 1 has been omitted from this format of the document.}

3. Methodology and research questions

The central research hypothesis of this paper is that the geography of air freight is systematically connected to the geography of metropolitan economic performance. More specifically, the hypotheses include:

- The geography of air freight by metropolitan area adheres to an explicit spatial hierarchy that is controlled by both the freight integrators at their major sorting hubs in the center of the country and several key international gateway destinations on the east and west coast.

- Variations in air freight activity by metropolitan area are largely a function of specific socioeconomic indicators such as overall measures of per capita income and skill levels given the propensity for air freight to proliferate in more sophisticated agglomerative economies that require high levels of connectivity and trade in time-sensitive, high-value, low-weight product shipments.

- The geography of air freight is directly linked to the composition of the metropolitan economy as measured by the percent of the labor force in key industries like transportation, shipping and logistics, high-tech and medical diagnostics. It will be argued that metropolitan economies that specialize in supply chain related industries will have a competitive advantage with respect to air freight shipments.

- The traffic shadow effect will play a significant role in shaping the geography of air freight whereby traffic diversion from smaller metropolitan areas to nearby larger metropolitan markets 
is a significant undercurrent to fully understanding the spatial variation of air freight at a metropolitan scale.

\subsection{Air freight definition}

Air freight is defined as revenue freight by pounds which includes all forms of property, other than mail and passenger baggage, transported by air (U.S, 2005a and U.S, 2009). The air freight data include shipments by foreign air carriers, large certificated air carriers, domestic all-cargo air carriers, and small certificated and commuter air carriers (U.S. BTS, 2005b). It should be noted that air freight at military airports was not included in this analysis given the fundamentally different nature of military airports relative to civilian airports.

Although this paper focuses on air freight weight (pounds) since it is more widely and publicly available relative to air freight data by value (\$), it is clear that a systematic relationship exists between air freight weight and value. A Spearman's correlation coefficient was calculated for air freight weight (pounds) and value (\$) using the U.S. Department of Commerce data for the 31 largest airports in the United States for 2003. The correlation coefficient of 0.36 was significant at the $5 \%$ level. The 31 airports included in this analysis accounted for $77 \%$ of the national market share for air freight value exports by airport suggesting that air freight measured by weight is an adequate surrogate for air freight as measured by value.

Air freight data were collected for all origin airports that generated more than $100,000 \mathrm{lb}$ in 2003. Much like the FAA-defined passenger enplanements (i.e., boarding passengers), air freight data are based on flight departures not arrivals. Consequently, air freight that is shipped via two or more connecting flights will then be counted multiple times. Consequently, the air freight data used in this paper not only captures the significance of originating markets but it also captures the significance of air freight hub markets like Memphis where the freight is frequently resorted and transferred onto a flight for the final destination.

Also, it should be noted that since labor markets tend to be metropolitan-wide not exclusively city-based in terms of actual work trip commuting behavior, the air freight data were collected by Metropolitan Statistical Area (MSA) and Combined Statistical Area (CSA) based upon the June 6, 2003 definitions of the U.S. Office of Management and Budget. The air freight data were aggregated for those metropolitan areas that had multiple airports within a single MSA or CSA. Overall, the data set included the largest 110 metropolitan areas with comprehensive socioeconomic and industrial data. It should be noted that some relatively large metropolitan areas were left out of the analysis due to incomplete data. Some of the economic data did not meet the 
disclosure restrictions required by the Federal Government including places like Anchorage, Columbia (SC), and Columbus (OH).

\section{Findings}

\subsection{Spatial distribution of air freight by metropolitan area}

In 2003, the average air freight volume shipped by metropolitan area was 232 million pounds varying from a high of 3.9 billion pounds in Memphis to a low of 125,529 lb in Columbus, GA (Fig. 2). Table 1 lists the fifteen metropolitan areas that generated the largest air freight demand and these markets collectively accounted for two-thirds of the total air freight poundage in the U.S. The top five largest markets included Memphis, Los Angeles, New York, Louisville, and Miami which collectively accounted for $40 \%$ of the U.S. total. Thus, just a few air freight nodes appear to substantially influence the national network indicating that a process of intense geographic concentration and regional specialization is fundamentally shaping the geography of air freight in the United States.

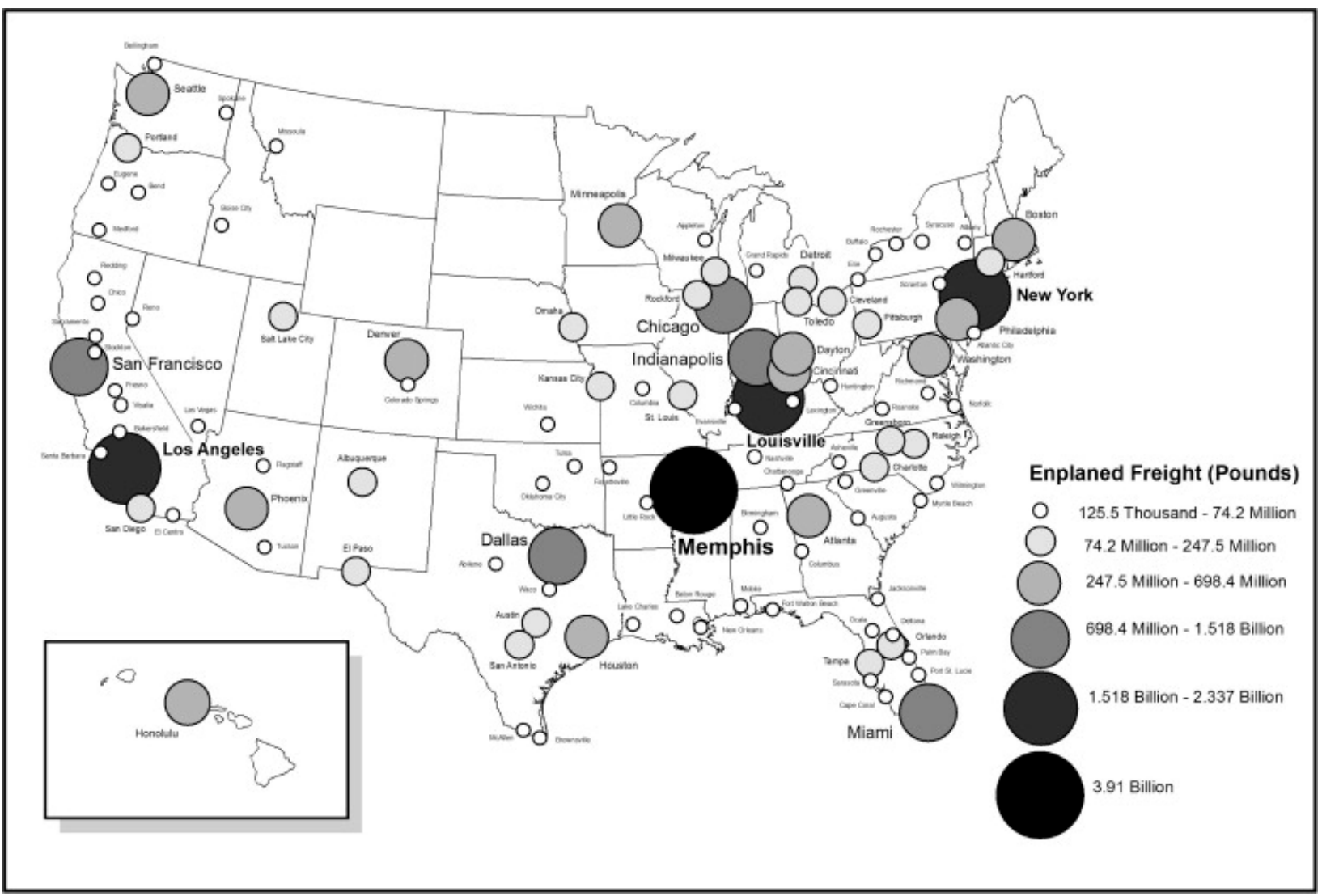

Fig. 2. Spatial distribution of total domestic and international enplaned freight (Pounds) by metropolitan area, 2003. Source: author's calculations based on data extracted from U.S. BTS (2005d). 
Table 1. Largest Air freight markets by metropolitan area, 2003.

\begin{tabular}{|c|c|c|c|}
\hline Rank & $\begin{array}{l}\text { Metropolitan statistical } \\
\text { area/combined statistical } \\
\text { area }\end{array}$ & $\begin{array}{l}\text { Total domestic and } \\
\text { international enplaned freight } \\
\text { (Pounds) }\end{array}$ & $\begin{array}{l}\text { \% Share of U.S. total domestic } \\
\text { and international enplaned freight } \\
\text { by weight }\end{array}$ \\
\hline 1 & Memphis, MSA & $3,911,091,183$ & 13.40 \\
\hline 2 & $\begin{array}{l}\text { Los Angeles-Long Beach- } \\
\text { Riverside, CSA }\end{array}$ & $2,337,955,813$ & 8.01 \\
\hline 3 & $\begin{array}{l}\text { New York-Newark- } \\
\text { Bridgeport, CSA }\end{array}$ & $2,164,841,988$ & 7.42 \\
\hline 4 & $\begin{array}{l}\text { Louisville-Elizabethtown- } \\
\text { Scottsburg, CSA }\end{array}$ & $1,821,149,366$ & 6.24 \\
\hline 5 & $\begin{array}{l}\text { Miami-Fort Lauderdale-- } \\
\text { Miami Beach, MSA }\end{array}$ & $1,518,866,711$ & 5.20 \\
\hline 6 & $\begin{array}{l}\text { San Jose-San Francisco-- } \\
\text { Oakland, CSA }\end{array}$ & $1,337,720,693$ & 4.58 \\
\hline 7 & $\begin{array}{l}\text { Chicago-Naperville-- } \\
\text { Michigan, CSA }\end{array}$ & $1,216,327,390$ & 4.17 \\
\hline 8 & $\begin{array}{l}\text { Indianapolis-Anderson- } \\
\text { Columbus, CSA }\end{array}$ & $981,910,898$ & 3.36 \\
\hline 9 & Dallas-Fort Worth, CSA & $870,003,045$ & 2.98 \\
\hline 10 & $\begin{array}{l}\text { Atlanta-Sandy Springs- } \\
\text { Gainesville, CSA }\end{array}$ & $698,390,018$ & 2.39 \\
\hline 11 & $\begin{array}{l}\text { Philadelphia-Camden- } \\
\text { Vineland, CSA }\end{array}$ & $613,764,469$ & 2.10 \\
\hline 12 & $\begin{array}{l}\text { Cincinnati-Middletown- } \\
\text { Wilmington, CSA }\end{array}$ & $490,243,431$ & 1.68 \\
\hline 13 & $\begin{array}{l}\text { Seattle-Tacoma-Olympia, } \\
\text { CSA }\end{array}$ & $464,410,426$ & 1.59 \\
\hline 14 & $\begin{array}{l}\text { Boston-Worcester- } \\
\text { Manchester, CSA }\end{array}$ & $443,043,955$ & 1.52 \\
\hline 15 & Honolulu, MSA & $420,566,720$ & 1.44 \\
\hline
\end{tabular}




\begin{tabular}{|c|c|c|c|}
\hline Rank & $\begin{array}{l}\text { Metropolitan statistical } \\
\text { area/combined statistical } \\
\text { area }\end{array}$ & $\begin{array}{l}\text { Total domestic and } \\
\text { international enplaned freight } \\
\text { (Pounds) }\end{array}$ & $\begin{array}{l}\text { \% Share of U.S. total domestic } \\
\text { and international enplaned freight } \\
\text { by weight }\end{array}$ \\
\hline & Total & $19,290,286,106$ & 66.08 \\
\hline
\end{tabular}

Source: Author' s calculations based on data extracted from U.S. BTS (2005d).

One major factor that may have triggered the intense geographic concentration of air freight demand to just a few select metropolitan areas is the rapid growth of the express parcels industry. In $2003,79.6 \%$ of all air freight was carried by the all-cargo carriers while just $20.3 \%$ was carried by passenger/cargo combination carriers (Fig. 3). The express parcels business has largely been dominated by two all-cargo carriers - FedEx and UPS. These two companies realized early on that the traditional passenger airlines were overlooking two key aspects of the air freight market. These needs included the high-speed delivery of small packages and door-todoor delivery service. Traditionally, passenger airlines mainly focused on providing airport-toairport freight delivery and largely depended on other intermediaries like freight forwarders for pick up and delivery to the final customer.

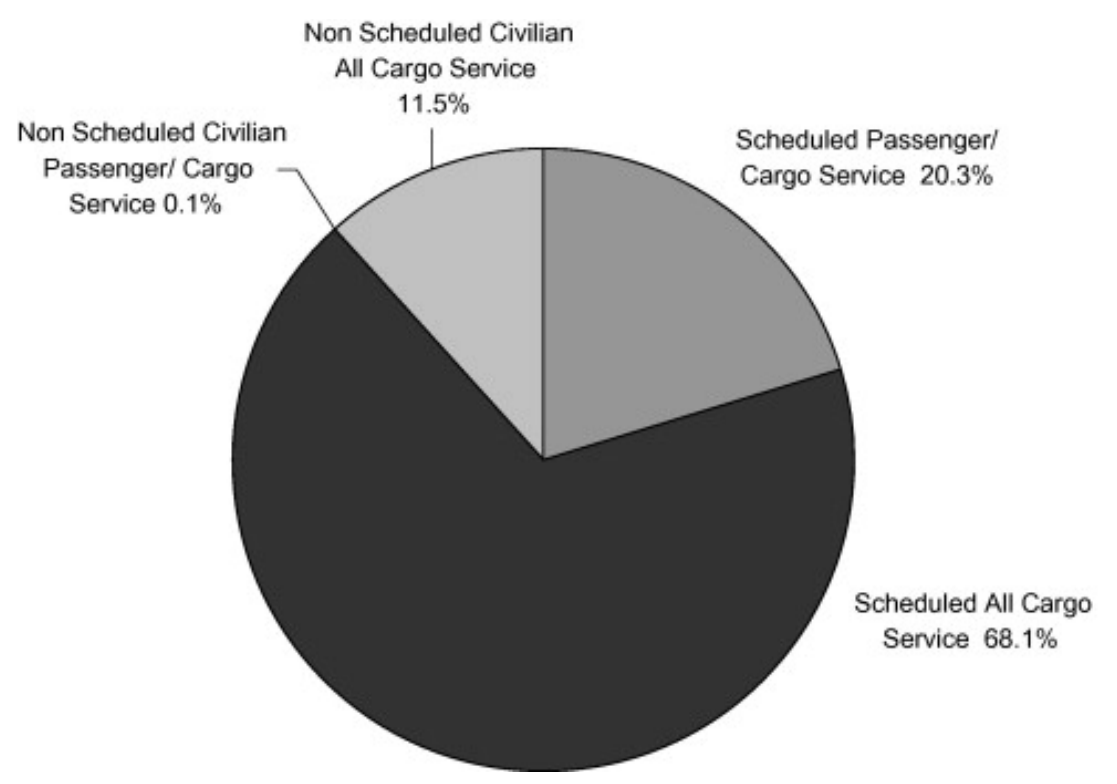

Fig. 3. U.S. international and domestic enplaned freight by class service (\%), 2003. Source: data were extracted from U.S. BTS (2005e).

Integrators (like FedEx and UPS) and several combination carriers (like Delta and American Airlines) are examples of carrier types that adopted a hub-and-spoke strategy after airline deregulation. However, these four carriers are characterized by several notable differences in the levels of spatial concentration of their operation and the nature of their distribution networks that requires additional explanation if we are to fully understand the geography of air freight markets in the United States. 


\subsubsection{The integrated all-cargo carrier hub markets}

The rise of all-cargo integrators (like FedEx and UPS) during the 1970s led to dramatic changes in both the air cargo industry and the overall national economy. Because of their reliable and fast delivery services coupled with on-time door-to-door distribution, the all-cargo integrators' services became increasingly valuable to manufacturers, retailers, and consumers. For example, the short life expectancy of perishable products (e.g., magazines, flowers, and fresh fruits) and increasingly fickle consumer spending behavior regarding brand loyalty elevated the importance of speed of delivery. In 2003, FedEx shipped by air over 10.2 billion pounds of air freight (44\% of the U.S. total) domestically, while UPS shipped over 5.4 billion pounds ( $24 \%$ of U.S. total).

Both FedEx and UPS have operated the bulk of their network out of a small number of mediumsized metropolitan markets that featured a combination of either surplus airport capacity, a business-friendly environment and/or were strategically located in the center of the country (e.g., Memphis, Louisville, and Indianapolis) (Fig. 2). These carriers have also extended the hub-andspoke model and established additional regional mini-hubs in places like Newark (NJ), Oakland (CA), Ontario (CA), and Miami (FL). These regional hubs were usually located in large gateway markets and satisfied regional niches by absorbing the surplus freight from surrounding large airports that were suffering from high levels of congestion and limited terminal capacity.

In 2003, Memphis was the largest air freight metropolitan market in the United States accounting for $13.4 \%$ of the U.S. total in enplaned freight. Of that total, only 224 million pounds (5.7\%) were shipped internationally while over 3.6 billion pounds (94.3\%) were distributed domestically confirming that Memphis International Airport largely operates as a domestic hub. Air freight traffic in Memphis is significantly larger than any other metropolitan market and it generated more than twice the overall freight weight shipped through Louisville as part of the UPS hub. Five out of the top fifteen destinations originating from Memphis were regional hubs for FedEx including Newark, Miami, Dallas, Anchorage, and Oakland (Table 2). Much like FedEx, UPS operated a large hub-and-spoke network from Louisville. In 2003, UPS shipped over 47.6 million pounds internationally but distributed more than 1.7 billion pounds domestically suggesting UPS has a similar domestic/international mix to that of FedEx.

Table 2. Proportion of FedEx's freight traffic originating in Memphis for other destinations in 2003. 


\begin{tabular}{|c|c|c|c|}
\hline Rank & Destination & $\begin{array}{l}\text { Enplaned freight } \\
\text { (Pounds) }\end{array}$ & $\begin{array}{l}\text { Destination share (\%) of FedEx's } \\
\text { total enplaned freight originating } \\
\text { from Memphis }\end{array}$ \\
\hline 1 & Newark, NJ & $128,613,160$ & 3.4 \\
\hline 2 & Los Angeles, CA & $126,289,380$ & 3.3 \\
\hline 3 & Orlando, FL & $93,220,200$ & 2.4 \\
\hline 4 & Seattle, WA & $87,748,320$ & 2.3 \\
\hline 5 & Chicago, IL & $86,569,860$ & 2.3 \\
\hline 6 & Miami, FL & $82,984,056$ & 2.2 \\
\hline 7 & $\begin{array}{l}\text { Dallas/Ft.Worth, } \\
\text { TX }\end{array}$ & $79,874,520$ & 2.1 \\
\hline 8 & New York, NY & $75,239,060$ & 2.0 \\
\hline 9 & $\begin{array}{l}\text { Ontario/San } \\
\text { Bernardino, CA }\end{array}$ & $73,532,980$ & 1.9 \\
\hline 10 & Boston, MA & $72,542,880$ & 1.9 \\
\hline 11 & Philadelphia, PA & $72,136,540$ & 1.9 \\
\hline 12 & Denver, CO & $70,184,100$ & 1.8 \\
\hline 13 & Anchorage, AK & $68,471,994$ & 1.8 \\
\hline 14 & Oakland, CA & $68,331,760$ & 1.8 \\
\hline \multirow[t]{2}{*}{15} & Atlanta, GA & $65,997,780$ & 1.7 \\
\hline & Total & $1,251,736,590$ & 32.8 \\
\hline
\end{tabular}

Source: Author' s calculations based on information extracted from U.S. BTS (2005f).Note: Bold face indicates FedEx Hub.

4.1.2. Combination carriers: traditional passenger connecting hubs 
Since $20.3 \%$ of the U.S. air freight market in 2003 was accounted for by the combination carriers (Fig. 3), it is important that we better understand the geography of combination carriers and their influence on air freight markets. Combination carriers can be classified into both legacy carriers (e.g., United, American and Delta) and low-cost carriers (e.g., Southwest Airlines). Combination carriers largely operate in intermediate connecting hubs but also in specific global gateway markets like Los Angeles and New York. This differential geography reflects the distinct competitive advantage of each of these places and the diverse strategies that combination carriers practice in individual markets.

In most cases, the combination carriers were dwarfed in size in most markets by the all-cargo air carriers. For example, although United Airlines and American Airlines established major connecting passenger hubs at Chicago O'Hare Airport during the 1980s, they collectively handled just $14.5 \%$ of O'Hare Airport's total enplaned freight in 2003. On the other hand, air freight integrators had a much stronger presence at O’Hare, where FedEx and UPS combined handled $25.7 \%$ of all air freight by weight. Furthermore, even though the Dallas-Fort Worth International Airport is the base for American Airlines, the carrier handled less than $15 \%$ of enplaned freight at the airport in 2003. By contrast, UPS and FedEx combined accounted for $51 \%$ of the originating air freight traffic at Dallas-Fort Worth Airport.

\subsubsection{International gateways}

The geography of the U.S. air freight market is also well established in four key international gateways, including Los Angeles, New York, Miami, and San Francisco (Fig. 2). In 2003, these four metropolitan areas collectively shipped $25.21 \%$ of total U.S. enplaned freight (Table 1 ). The large market shares partly related to the diversity of their respective gateway economies, as well as the substantial transportation infrastructures and sophisticated multimodal distribution systems located in each city. The high level of international air traffic at these gateways reflects their role as significant global nodes of commercial activity. The important role of the combination carriers in carrying substantial amounts of this freight traffic across international routes should not be under-estimated. Many U.S. and foreign passenger carriers operate in the gateway markets and ship considerable air freight in the bellyhold to a wide range of global destinations.

The Los Angeles air freight market is largely driven by its international trade, entertainment, aerospace, technology, petroleum, fashion, apparel, tourism, and health and medicine industries. LAX Airport shipped the highest percentage (71.81\%) of the Los Angeles-CSA total enplaned pounds, and it is a major gateway to many international destinations in Latin America, Europe, Asia, and Oceania. Even though it is a major hub for United Airlines and Alaska Airlines in 
terms of passengers, these carriers shipped a smaller share of LAX's total enplaned freight. For example, in 2003, United Airlines accounted for 5.57\% of the airport enplaned freight, while FedEx shipped $23.29 \%$ of the airport's total enplaned pounds.

The San Francisco-CSA is another significant Pacific gateway with substantial air freight traffic (1.3 billion enplaned pounds $-4.58 \%$ of U.S. total) that is largely related to the high concentration of semiconductor and computer-related industries at the Silicon Valley in southern San Francisco. Also, positioning San Francisco as a biotechnology and biomedical hub and research center increased its dependence on air transport. That said, the Oakland Airport generated more enplaned freight (677 million pounds) than the San Francisco Airport (546 million pounds) even though San Francisco Airport is a much larger air passenger market. The capacity constraints at San Francisco Airport seem to have helped Oakland Airport emerge as an air cargo hub for both FedEx and UPS (with a market share at Oakland Airport of 82.56\% and $14.09 \%$, respectively.

\subsubsection{Overall trends}

Overall, there is a substantial geographic concentration and specialization of air freight operations across a select few U.S. markets. More specifically, the geography of air freight has largely clustered in some 'intermediate’ domestic hubs (e.g., Memphis, Louisville, and Indianapolis) and in some sophisticated and diverse international gateways (e.g., Los Angeles, New York, Miami, and San Francisco). The concentration of air freight traffic at these 'intermediate' metropolitan markets is largely related to the specialized services of the all-cargo integrators (e.g., FedEx and UPS) in sorting and reshipping cargo to other U.S. domestic destinations and overseas. However, air freight traffic at the international gateways is largely related to the agglomeration of diverse economies, an intense geographic concentration of freight forwarders, as well as a proliferation of passenger carriers that transport substantial amounts of freight across international routes. It should also be noted that the "Big Three" passenger carriers (e.g., American, United, and Delta) have tended to capture a much smaller share of U.S. shipments at their air passenger hub airports compared to the all-cargo integrators in those same markets. Even in passenger hub markets like Chicago and Dallas, FedEx and UPS often times carried twice as much air freight relative to the dominant passenger airlines at each of these airports.

\subsection{The regression analysis}


A stepwise regression analysis was performed to examine the relationship that existed between air freight demand and a group of predictor variables using SPSS (version 10.0).

\subsubsection{The predictor variables}

We identified 33 potential independent variables (Table 3) that have been suggested as potential predictors for the spatial distribution of air freight by metropolitan area. Unless otherwise noted, most of the data came from the U.S. Department of Commerce Bureau of Economic Analysis (BEA, 2005) or the U.S, 2005 and U.S, 2009a. The socio-economic characteristics that were addressed in this paper included the following:

- Total population: Some of the literature (e.g., Taaffe, 1956 and Goetz, 1992) has suggested that the critical mass of the market as measured by total population is a key factor influencing air freight markets and passenger hubs.

- Population growth rate (2000-2003): It is expected that fast growing metropolitan areas will tend to attract a disproportionate share of innovative, knowledge economy industries that tend to be more likely to ship time-sensitive, high-value, and low-weight products.

- Total personal income (\$): Much like with total population, some studies have suggested that the overall aggregate wealth of a metropolitan area is a key predictor of air freight performance.

- Per capita personal income (\$): It is expected that metropolitan areas with high per capita personal income ship high rates of air freight poundage.

- Percent population in poverty: It is hypothesized that metropolitan areas with a large percent of people living in poverty will tend to underperform regarding air freight shipments.

- Education: total population with a BA and higher (25-64 years old): Well-educated markets tend to reflect above average skill sets which can generate a disproportionate amount of high value-low weight products that tend to be shipped by air.

Table 3. List of independent variables included in the study.

\# Independent variables

1 High-tech employment

2 High-tech establishments

3 High-tech total wages 
\# Independent variables

$4 \quad$ High-tech employment market share

5 Average high-tech employee wage

$6 \quad$ Medical diagnostic employment

$7 \quad$ Medical diagnostic establishments

8 Medical diagnostic total wages

9 Medical diagnostic employment market share

10 Average medical diagnostic employee wage

11 Pharmaceutical and biotech employment

12 Pharmaceutical and biotech establishments

13 Pharmaceutical and biotech total wages

14 Pharmaceutical and biotech employment market share

15 Average pharmaceutical and biotech employee wage

16 Cultural products employment

17 Cultural products establishments

18 Cultural products total wages

19 Cultural products employment market share

20 Average cultural products employee wage

21 Transportation-shipping-logistics employment

22 Transportation-shipping-logistics establishments

23 Transportation-shipping-logistics total wages

24 Transportation-shipping-logistics employment market share

25 Average transportation-shipping-logistics employee wage

26 Total population

27 Total personal income 
\# Independent variables

28 Per capita personal income

29 Total employment in all industries

30 Percent population in poverty

31 Total population (25-64 years) with bachelor’s degree or higher (2005)

32 Percent growth rate of population (2000-2003)

33 Traffic shadow effect

It is also hypothesized based on the existing literature (Doganis, 1991, Haggerty, 2004, O’Connor, 2001, Kasarda and Green, 2005, Dicken, 2007, Milken Institute, 2004 and Brookings Institution, 2002) that certain key manufacturing activities tend to ship a disproportionate level of air freight including cultural products, high-tech, medical diagnostic, pharmaceutical and biotech, and transportation-shipping-logistics. Data for these indicators were collected from the Quarterly Census of Employment and Wages (QCEW) program that is available through the U.S. Bureau of Labor Statistics (BLS, 2005). Each industry was defined based on the North American Industrial Classification System (NAICS) which is utilized by the Federal Government to classify industry nationwide. It is hypothesized that as the economic indicators for these sectors of the economy increase as measured by number of jobs, establishments and average wages that air freight shipments will increase in a similar fashion. The specific industries analyzed in this paper included:

- Cultural products: Jewelry and cosmetic goods: High-value, low-weight products like pearls, stones, and metals imitation jewelry were one of the four most important commodities regarding air freight shipments in the NAFTA region in 2004 (U.S. BTS, 2005c). Therefore, this paper investigates empirically the relationship that exists between air freight weight and jewelry and cosmetic products and includes the following industries:

○ NAICS 42394: Jewelry, watch, precious stone, and precious metal merchant wholesalers

○ NAICS 33991 Jewelry and silverware manufacturing

○ NAICS 44612 Cosmetics, beauty supplies, and perfume stores

- High-tech industries: Many hi-tech products such as various computer parts and related electronic products are shipped by air. These industries included: 
○ NAICS 5415: Computer systems design and related services

○ NAICS 334: Computer and electronic product manufacturing

- Medical diagnostic and supplier industries: Given the requirement for the rapid delivery of diagnostic results to clients and the usually low weight/high value product type, this sector is particularly susceptible to shipments by air. These industries included:

○ NAICS 42345: Medical, dental, and hospital equipment and supplies wholesalers

○ NAICS 6215: Medical and diagnostic laboratories

○ NAICS 33911: Medical equipment and supplies manufacturing

- Pharmaceutical and biotech industries: Like previous biotechnology studies conducted by the Milken Institute (2004) and the Brookings Institution (2002), this paper will choose the following NAICS codes to represent the pharmaceutical and biotech sectors:

- NAICS 32541: Pharmaceutical and medicine manufacturing

○ NAICS 5417: Scientific research and development services

- Transportation-shipping-logistics industries: Although this sector does not directly manufacture products that generate air freight, it is crucial in facilitating air freight movement. It included the following industries:

○ NAICS 4921: Couriers

○ NAICS 49311: General warehousing and storage

○ NAICS 49319: Other warehousing and storage

○ NAICS 4885: Freight transportation arrangement

○ NAICS 488991: Packing and crating

The quality and quantity of these manufacturing-related industrial activities will be assessed based on five economic indicators: number of establishments, number of employees, total wages (\$), employment market share (\%), and average employee wage rate (\$).

We also utilized a modified version of Brueckner's (2003) proximity variable to capture the traffic shadow effect. It is hypothesized that freight shippers located in small and medium-sized metropolitan areas that are located fairly close to larger metropolitan markets will tend to ship freight by ground to the larger airport due to the proliferation of flight connections and flight services in the larger markets, thus, reducing freight shipment volume in the smaller markets. In 
order to capture the traffic diversion effect, we constructed a dummy variable to capture the 'traffic shadow effect'. The variable is set equal to one for smaller metropolitan areas that generated less than 30 million pounds in air freight volume, and are within 100 miles of a metropolitan area containing a large airport (that generated more than 30 million pounds in air freight). Although the cut-off between large and small airports is partly arbitrary, it is also based on a significant 'natural break' in the dataset just below the freight weight median value of 45.6 million pounds by metropolitan area.

\subsubsection{The regression model}

A natural log transformation of air freight was performed because of the high level of positive skew in the dependent variable, and the nonlinear relationship that existed with many of the predictor variables. Different diagnostic tests were also conducted to check for multicollinearity, anomalies, linearity, normality of the residuals, and the homogeneity of variance. The final chosen model exhibited no serious multicollinearity problems among the selected independent variables and met most of the assumptions of linearity, normality, and homoscedasticity.

The R-squared in the final regression model suggested that $71.1 \%$ of the variation in air freight demand by metropolitan area was accounted for by five predictor variables including the traffic shadow effect, the percentage of the labor force employed in transportation logistics, per capita personal income, the number of medical diagnostic establishments, and high-tech wages. The standardized and unstandardized coefficients for the independent variables are listed in Table 4. Using the unstandardized b coefficients, the estimated regression equation is:

$$
\begin{aligned}
\mathrm{LN}(\mathrm{AF})= & 4.782-0.969 \mathrm{TSE}+0.661 \mathrm{TSL}+0.055 \mathrm{PC}+0.001 \mathrm{MD} \\
& +0.01 \mathrm{HT}
\end{aligned}
$$

where LN (AF) = logarithm of air freight; TSE = traffic shadow effect; TSL = transportationshipping-logistics employment market share (\%); PC = per capita personal income (\$1000); MD =\# of medical diagnostic establishments; HT = average high-tech employee wage $(\$ 1000)$.

\begin{tabular}{|c|c|c|c|c|c|c|}
\hline \multirow[t]{2}{*}{ Model } & $\begin{array}{l}\text { Unstandardized } \\
\text { coefficients }\end{array}$ & $\begin{array}{l}\text { Standardized } \\
\text { coefficients }\end{array}$ & $t$ & $\begin{array}{l}P \text { - } \\
\text { Value }\end{array}$ & $\begin{array}{l}\text { Change in air } \\
\text { freight as a } \\
\text { ratio = exp }(B)\end{array}$ & $\begin{array}{l}\text { Change in Air } \\
\text { freight }(\%)=[\exp \\
(B)-1]^{*} 100\end{array}$ \\
\hline & $\begin{array}{l}\text { Std. } \\
\text { error }\end{array}$ & Beta & & & & \\
\hline
\end{tabular}

Table 4. The final regression model. 


\begin{tabular}{|c|c|c|c|c|c|c|c|}
\hline \multirow[t]{2}{*}{ Model } & \multicolumn{2}{|c|}{$\begin{array}{l}\text { Unstandardized } \\
\text { coefficients }\end{array}$} & \multirow[t]{2}{*}{$\begin{array}{l}\text { Standardized } \\
\text { coefficients }\end{array}$} & \multirow[t]{2}{*}{$t$} & \multirow[t]{2}{*}{$\begin{array}{l}P \text { - } \\
\text { Value }\end{array}$} & \multirow{2}{*}{$\begin{array}{l}\text { Change in air } \\
\text { freight as a } \\
\text { ratio }=\exp (B)\end{array}$} & \multirow{2}{*}{$\begin{array}{l}\text { Change in Air } \\
\text { freight }(\%)=[\exp \\
(B)-1]^{*} 100\end{array}$} \\
\hline & $B$ & $\begin{array}{l}\text { Std. } \\
\text { error }\end{array}$ & & & & & \\
\hline Constant & 4.782 & .436 & & 10.978 & .000 & & \\
\hline Traffic shadow effect & -.969 & .147 & -.366 & -6.581 & .000 & 0.379 & $-62 \%$ \\
\hline $\begin{array}{l}\text { Transportation- } \\
\text { shipping-logistics } \\
\text { employment market } \\
\text { share (\%) }\end{array}$ & .661 & .116 & .308 & 5.693 & .000 & 1.936 & $94 \%$ \\
\hline $\begin{array}{l}\text { Per capita personal } \\
\text { income }(\$ 1000)\end{array}$ & .055 & .016 & .237 & 3.327 & .001 & 1.056 & $6 \%$ \\
\hline $\begin{array}{l}\text { Medical diagnostic } \\
\text { establishment (\#) }\end{array}$ & .001 & .000 & .230 & 3.485 & .001 & 1.001 & $0.1 \%$ \\
\hline $\begin{array}{l}\text { Average high-tech } \\
\text { employee wage } \\
(\$ 1000)\end{array}$ & .010 & .004 & .170 & 2.594 & .011 & 1.010 & $1 \%$ \\
\hline
\end{tabular}

To better understand the relative importance of each predictor variable in accounting for the spatial variation in air freight, the absolute magnitudes of the beta coefficients (standardized regression coefficients) are provided in Table 4. Also, the t-test results are listed in Table 4 to show the significance of each b coefficient.

\subsubsection{The traffic shadow effect}

The traffic shadow effect was the most important variable in predicting the natural log of air freight $(\beta=-.366, t=-6.581, p=.000)$ (Table 4 ) accounting for $18.3 \%$ of the variation. Fig. 4 illustrates in more detail a hypothetical example of how the traffic shadow effect theoretically operates between two proximate metropolitan areas of unequal size. Companies generating highvalue, low-weight products that need to be shipped by air may be located closer to the smaller metropolitan area airport but prefer the more distant larger airport because it offers more flights, more destinations, and better services. It should be noted that since the data for air freight were collected by MSA/CSA, it is not possible to estimate the traffic shadow effect of different airports located within a single MSA or CSA. 


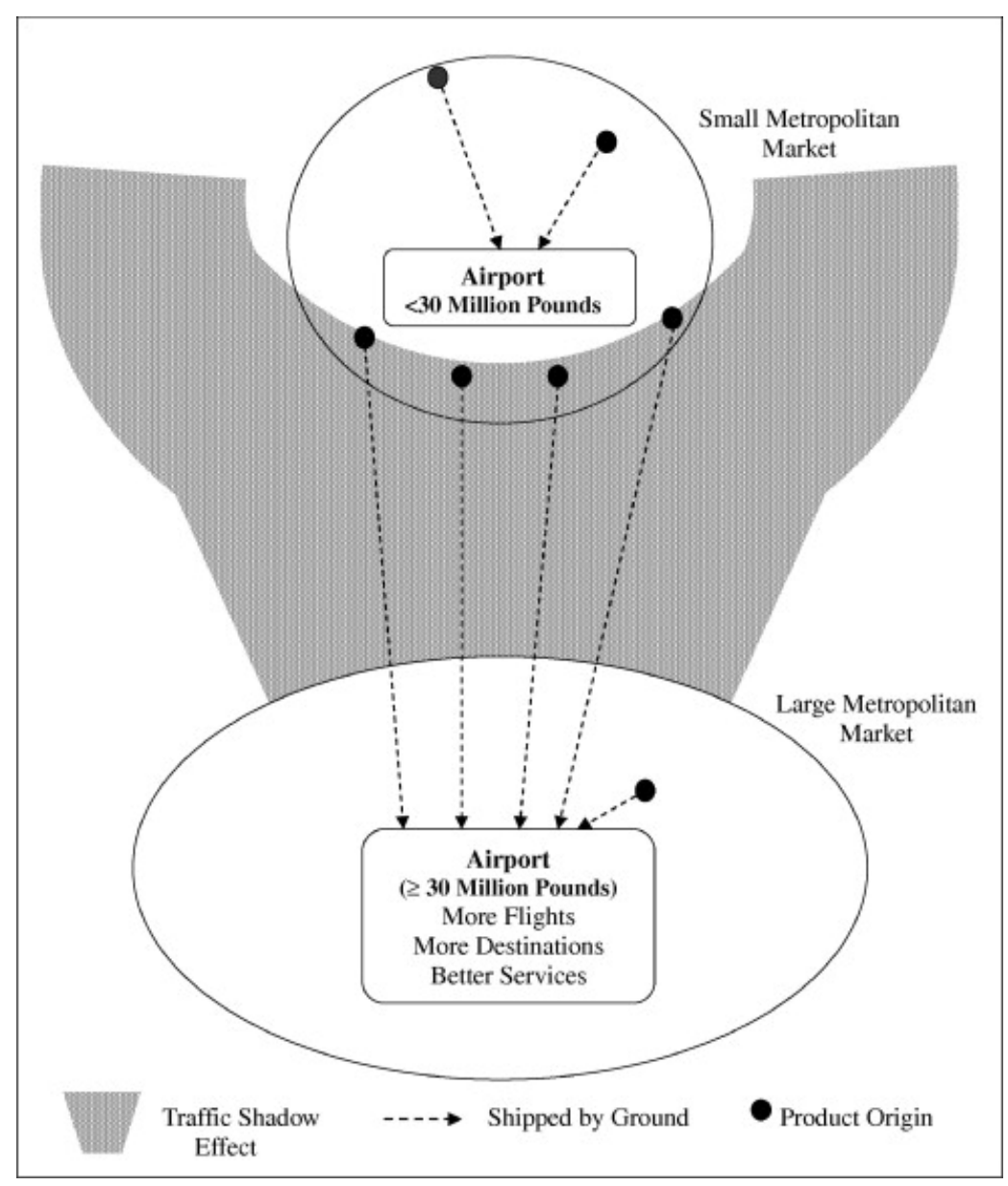

Fig. 4. Hypothetical traffic shadow effect between a large and small metropolitan market.

The traffic shadow effect substantially impacted the 26 metropolitan areas that generated less than 30 million pounds of freight but were located within 100 miles of a larger metropolitan area. The average freight volume of those metropolitan areas with small airports within the traffic shadow was 4.8 million enplaned pounds compared to an average of nearly 7.9 million enplaned pounds for those 'small' markets not within a traffic shadow. Part of the logic for this effect is the substantial impacts that the large airports have on attracting shippers and freight forwarders through their frequent flight schedules and more sophisticated cargo services.

The explicit contrast between traffic-shadow and nontraffic-shadow airports in terms of air freight volume clearly demonstrates the role geography can play in shaping air freight. A visual inspection of Fig. 5 also suggests at least two very different competitive contexts exist. Smaller airports that are under the traffic shadow effect of multiple larger markets tend to have more 'freight loss' than a small airport under the traffic shadow effect of only one large airport. The average freight volumes of small airports under the traffic shadow effect of one large airport was 
5.6 million enplaned pounds, while average freight volumes for small airports under the traffic shadow effect of more than one large airport was 3.3 million enplaned pounds.

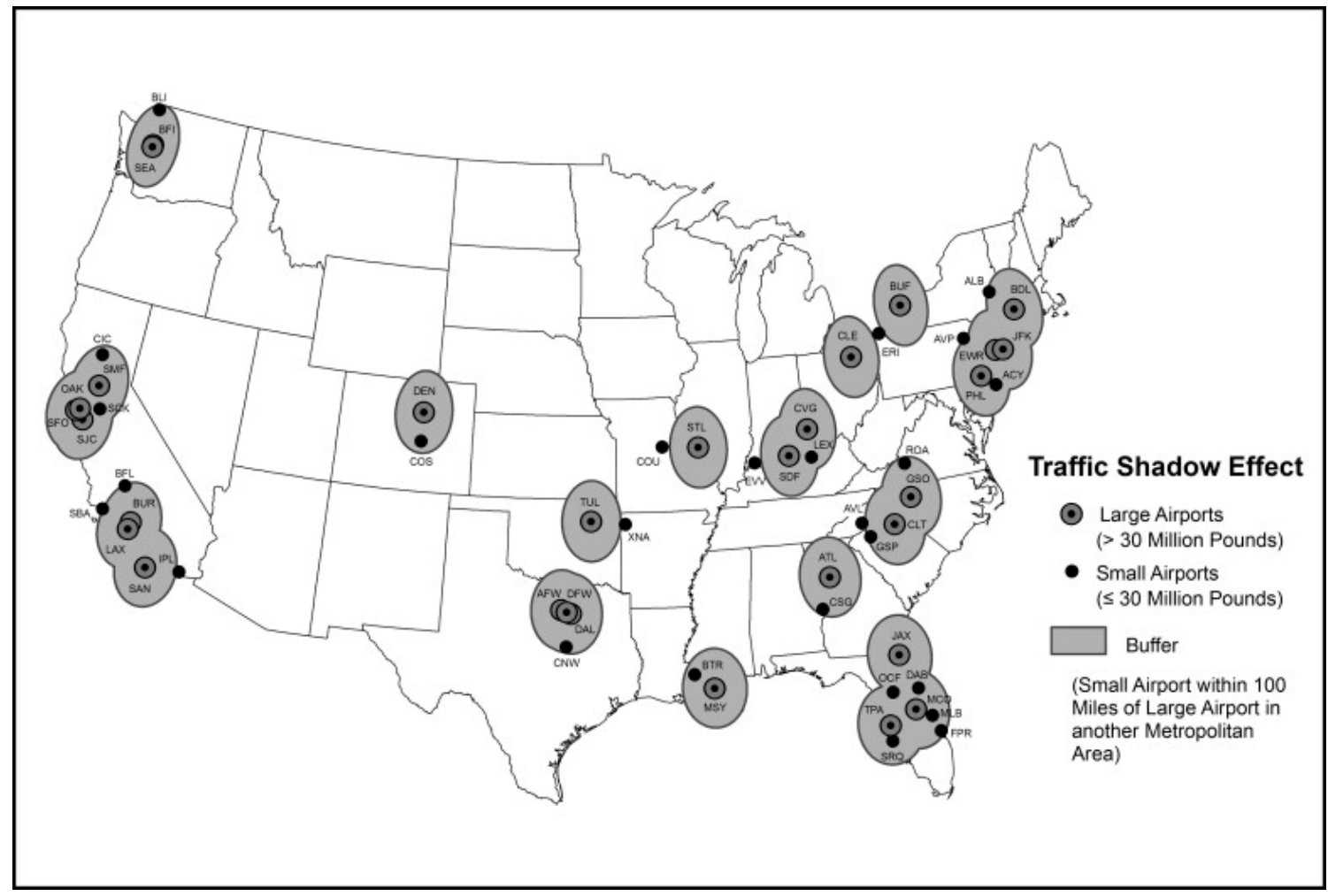

Fig. 5. The geography of the traffic shadow effect.

\subsubsection{Transportation-shipping-logistics (TSL) employment market share (\%)}

Based on the standardized coefficients, the TSL employment market share $(\beta=.308, \mathrm{t}=5.693, \mathrm{p}$ $=.000$ ) is the second most important independent variable in predicting the natural log of air freight within the model (Table 4). The diverse functional services of this sector of the economy are essential to facilitating freight processing and distribution. Although a majority of these services are focused exclusively on ground shipments, it appears that metropolitan economies that generated a disproportionate share of TSL services and employment experienced substantially elevated levels of air freight demand.

Curiously, although Memphis generated the most air freight demand, it only ranked twelfth in terms of TSL employment market share (1.26\%) (Fig. 6). Some of the logic for this may be due to the large proportion of air freight in Memphis that originates in other metropolitan areas and simply connects through Memphis. However, the positive relationship that exists between air freight demand and TSL employment market share is more clearly pronounced in other connecting hubs such as Louisville which ranked first in terms of TSL employment market 
share. The relationship between air freight and TSL employment market share is further complicated by the experiences of some smaller markets like Reno and Stockton. Reno and Stockton ranked second (2.23\%) and third (2.01\%) respectively in terms of TSL employment market share but generated surprisingly low levels of air freight (Fig. 6 and Fig. 2). Reno and Stockton remind us that much TSL employment has little do with air freight and more to do with low cost warehousing locations that emphasize largely ground-to-ground shipments by truck, or rail. Jacksonville, FL and Roanoke, VA also generated disproportionately large TSL employment shares even though air freight shipments in both markets were fairly low (Fig. 6 and Fig. 2). Much of the logic for this may be attributable to the fact that Jacksonville is a major port city while Roanoke is a main hub in Norfolk Southern's freight rail system.

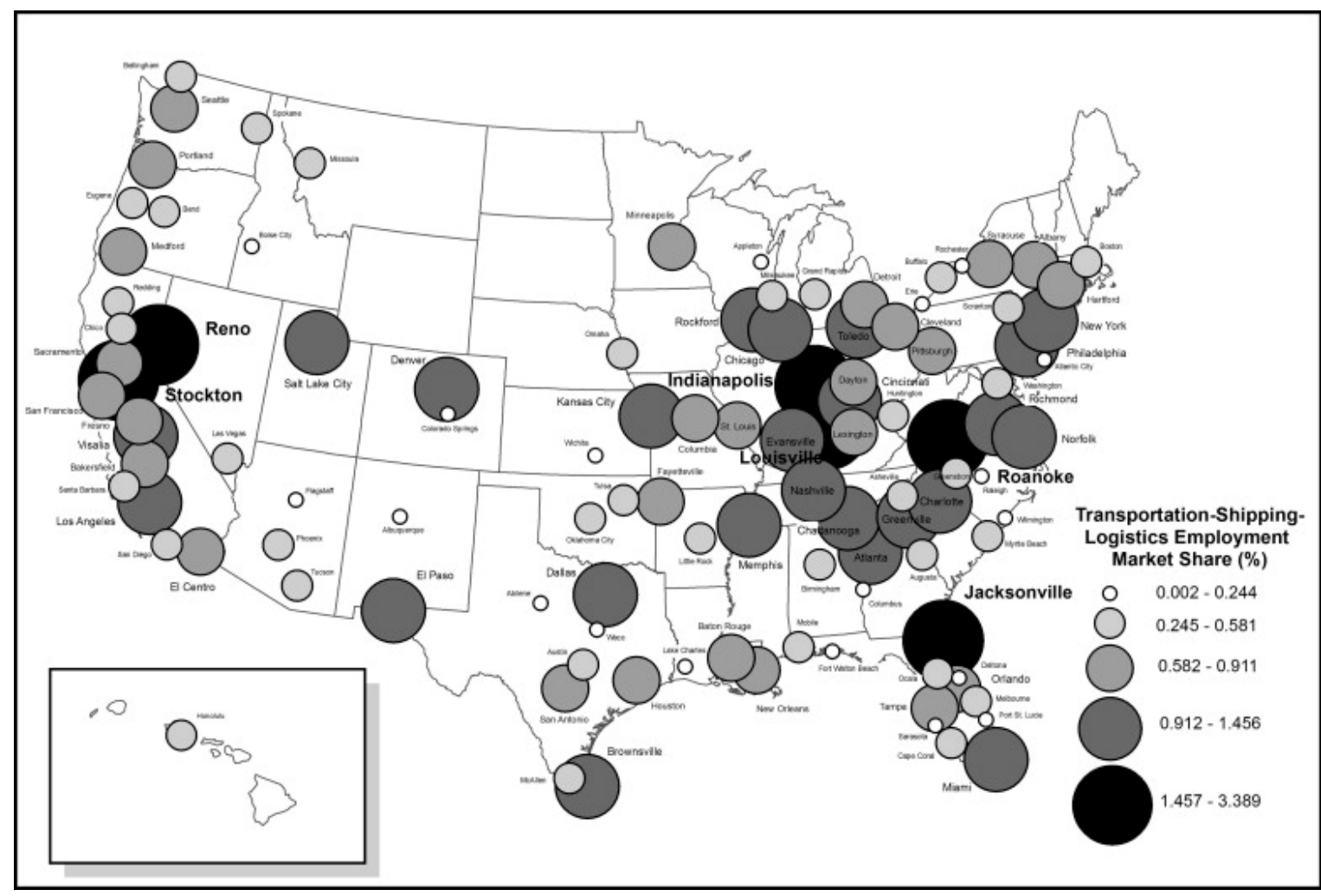

Fig. 6. The spatial distribution of transportation-shipping-logistics employment market share (\%), 2003. Source: author's calculations based on information extracted from BLS (2005).

Overall, the positive relationship that exists between TSL employment market share and air freight is fairly pronounced in some of the larger traditional metropolitan markets including New York, Los Angeles, Chicago, San Francisco, Dallas, and Miami. These markets have developed as leading air cargo markets and also function as major transportation and logistics centers in absolute and relative terms. The substantive TSL employments in these markets are partly related to their large population bases, diverse economies, and well-established multimodal logistic facilities. 


\subsubsection{Per capita personal income}

Variations in per capita income appear to be systematically linked to the geography of air freight by metropolitan area $(\beta=.237, \mathrm{t}=3.327, \mathrm{p}=.001)$. However, the relationship between air freight and per capita personal income is not a straightforward one. For example, Memphis generated the most air freight demand in 2003, but it only ranked 38th in per capita personal income ( Fig. 2 and Fig. 7). The high levels of air freight demand in Memphis are not necessarily a reflection of the local economy given the high proportion of connecting traffic. Similar relationships seem to apply to Louisville (UPS hub) and Indianapolis (FedEx hub). On the other hand, for some of the international gateway markets, a strong relationship appears to exist between per capita personal income and air freight, especially in New York. In 2003, New York ranked fourth $(\$ 40,842)$ in terms of per capita personal income and ranked third in terms of air freight, with more than 2.164 billion pounds. The role of New York in shaping the geography of air freight is likely more connected to its broader role as a World City with its preponderance of higher value-added services and elevated connectivity levels than with any single measure of wealth generation.

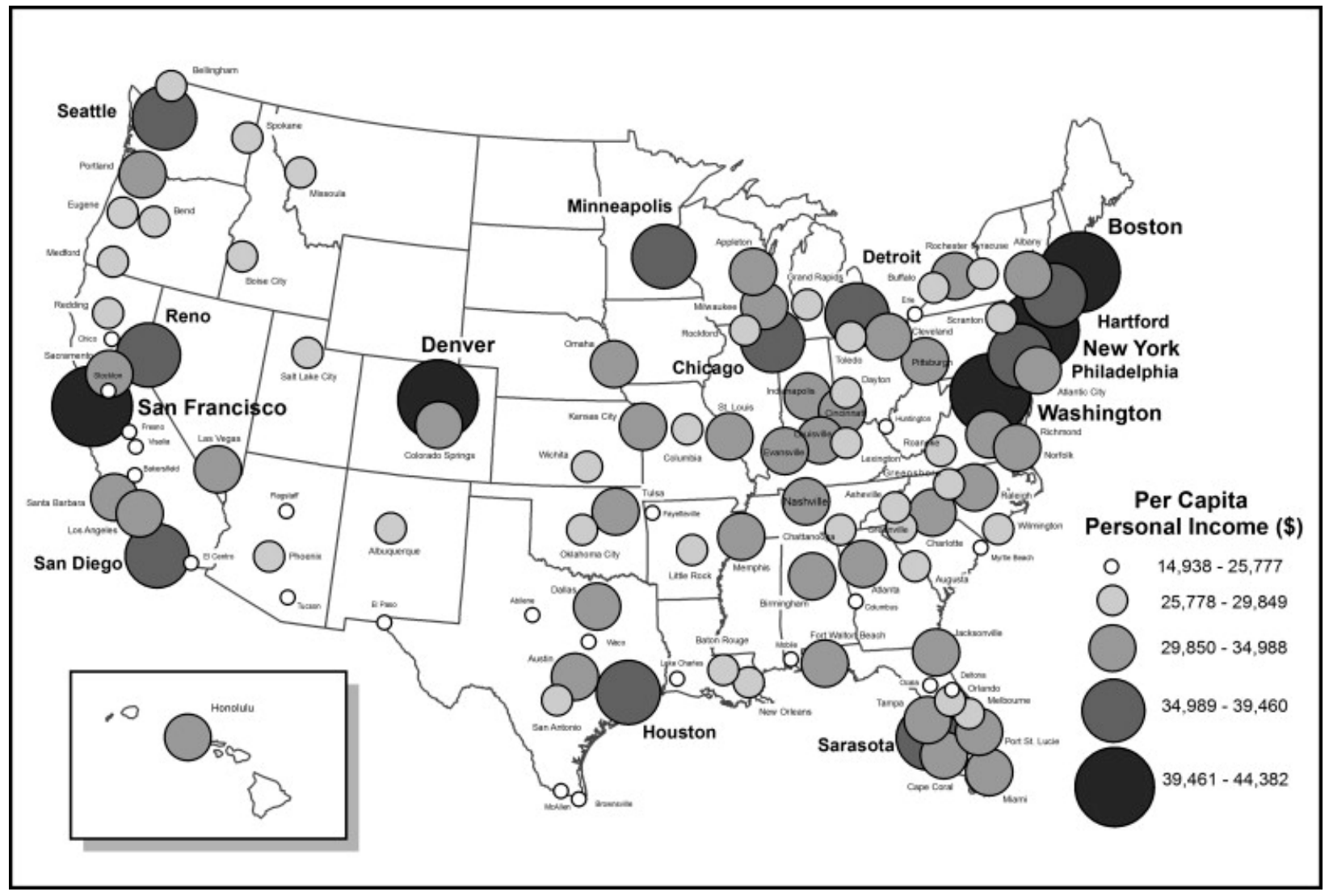

Fig. 7. The spatial distribution of per capita personal income, 2003. 


\subsubsection{Number of medical diagnostic and supplier establishments}

Based on the standardized Beta values, the number of medical diagnostic establishments was the fourth most important predictor of the natural $\log$ of air freight $(\beta=.230, t=3.485, p=.001)$ (Table 4). The suggestion here is that this sector of the economy is highly linked to air freight given the necessity for the quick delivery of diagnostic results to customers and the proliferation of high-value, low weight products. Firms engaged in wholesaling medical professional equipment, instruments, and supplies; providing analytic or diagnostic services; and manufacturing medical equipment and supplies all have high propensities to ship by air and metropolitan areas hosting a large number of different medical diagnostic firms seem to create a substantial demand for air freight. A complex and diverse cluster of medical diagnostic-related establishments was especially pronounced in the international air freight gateways (i.e., New York, Los Angeles, Miami, Chicago, Boston, and San Francisco). It seemed that the absolute size of the market as measured by establishments played a key role in shaping the geography of air freight. Once again, the major air freight sorting hubs did not feature prominently for this independent variable. Memphis, Louisville, and Indianapolis only ranked 41st, 42nd, and 26th, respectively, in terms of the number of medical diagnostic establishments.

\subsubsection{Average high-tech wages}

The fifth and final predictor to enter the model was average high-tech employee wages accounting for $1.9 \%$ of the variance in the natural log of air freight. The implication here is that metropolitan markets offering above average high-tech wage rates will experience elevated air freight shipment volumes. Metropolitan areas that can offer above average wages in highly skilled occupations in either computer systems design and related services or manufacturing computer and electronic products will have a higher tendency to generate significant air freight demand, all other things being equal. That said, affluent technology labor markets are not a panacea regarding air freight demand. Although Austin, TX and Raleigh, NC are world renowned high technology meccas neither featured as a top thirty metropolitan area for air freight, even though they ranked 6th and 7th, respectively, in terms of average high-tech wages. Part of the explanation is that some high-technology industry clusters thrive in smaller markets with intense concentrations of universities, skilled labor, and research and development services that may well produce reduced air freight volume in an absolute sense.

\subsubsection{Other variables?}

Other predictor variables targeted in the existing literature as potential indicators of air freight demand were not included in the final model because they either had a high level of multicollinearity with other independent variables and/or were less powerful predictors than the 
selected variables. For example, the pharmaceutical industry was not featured in the final regression model although this may be partly related to the fact that the air freight dependent variable is defined based on weight not value (\$). Additionally, the regression model assesses the contribution of independent variables interactively, and while the pharmaceutical industry is an important part of air freight demand it is not as crucial a determinant as other factors.

Although some of the existing literature (U.S, 2005c, Doganis, 1991, Haggerty, 2004 and O’Connor, 2001) has suggested that pharmaceutical, biotechnology, and the cultural products industries can play a substantial role in shaping air freight demand, the results in this paper suggest a more powerful predictor was the proportion of the metropolitan labor pool employed directly in transportation-shipping and logistics related industries. That said, TSL is only a powerful predictor variable when measured as a percent share of total employment, not as an aggregate indicator of the total number of jobs in TSL. Consequently, it is not the absolute size of the TSL market that is necessarily the key trigger for air freight, it is instead the level of TSL specialization in the metropolitan economy. By contrast, it was the actual number of medical diagnostic and supplier establishments that was selected to enter the final regression model and not the absolute or relative number of jobs in medical-related industries. This suggests that an agglomerative effect and a proliferation of medical-related firms and related inter-industry linkages tend to generate disproportionately high levels of high-value and low-weight goods and therefore substantial air freight demand. Apparently less relevant in this case were the absolute or relative number of high-technology jobs because it is average high-tech wages that best captures the skill levels needed to manufacture the sort of high-value and low-weight computer related products that need to be shipped by air. The assumption here is that wage rates are a crude proxy for skill levels and this may not always be the case.

\section{Conclusion and future implications}

The geography of air freight is an under-studied research arena despite its increasing importance as a key component of a firms' competitive advantage. It is not well understood how the appropriate mix of economic activity 'on the ground' shapes the geography of air freight 'in the air'. The analysis of the geography of air freight demand suggests a substantial spatial concentration and hierarchy of air freight volume exists in several intermediate cargo hubs like Memphis, Louisville, and Indianapolis and in a select few major international gateways (e.g., Los Angeles, New York, and San Francisco). A stepwise regression analysis suggested that metropolitan markets are more likely to ship freight by air if they offer a disproportionate TSL employment share, high per capita incomes, an intense agglomeration of medical related establishments, and offer above average wage rates in computer systems design and manufacturing. 
The most powerful influence appeared to be the traffic shadow effect where small metropolitan markets under the traffic shadow of larger metropolitan markets tended to produce lower levels of freight. Of course, some of the freight demand may not be from originating traffic but largely connecting trans-shipments, particularly in the FedEx and UPS freight hub markets. That said, the proliferation of air freight services associated with both originating and connecting markets is likely to attract certain sorts of businesses and industries over others. An important next step in this research agenda will likely be to isolate out the impact of originating versus connecting freight traffic by metropolitan area on important metropolitan indicators such as per capita personal income, educational attainment, and degree of employment in high-tech industries, medical diagnostic and supplier industries, and pharmaceutical and biotech industries.

Regarding the larger conceptual framework of this paper, it appears that the regression model provides some empirical evidence to buttress Kasarda's concept of aviation-centered metropolitan development. The positive relationships that exist between various measures of income, the electronics industry and the medical equipment industry seem to suggest that air freight can play a key role in shaping the regional economy in certain strategically located metropolitan areas. On the other hand, the demonstrated importance of the traffic shadow effect suggests that an aerotropolis strategy is not always guaranteed to succeed particularly in hub locations proximate to larger airports.

Future research should perhaps examine the traffic shadow effect in more detail by analyzing the impact on smaller airports located within each individual metropolitan area instead of just between metropolitan areas as in this paper. Some secondary airports have managed to successfully develop air freight hubs in the "shadow" of nearby larger airports in the same metropolitan area. The most obvious case may be Fort Worth Alliance Airport but local authorities have also tried to stimulate air freight-related economic development around Willow Run near Detroit. A more detailed analysis of how different TSL-related industries shape air freight demand might also be helpful especially through specific case studies focused on enhancing our understanding of how the TSL industry cluster operates in terms of product mix and inter-industry linkages within the cluster.

Overall, the geography of air freight reminds us of the crucial role that nodal connectivity and spatial hierarchies play in shaping air freight demand. Even with the recent economic recession, it is clear that speed of delivery and sophisticated supply chains will be a key part of any future competitive advantage. Better understanding the underlying geography of air freight can provide 
some insight into this evolving competitive advantage - it is likely a subject matter that will become more, not less, important in the years to come.

\section{References}

Al Chalabi, M., Kasarda, J. D., 2004. Airports: short- and long-term trends. In: Just in Time Real Estate: How Trends in Logistics are Driving Industrial Development, Washington, D.C.: ULI Urban Land Institute, pp. 81-104.

K. Alkaabi, K. Debbage. The geography of air transport and skilled labor markets by metropolitan area. Journal of Air Transport Management, 13 (3) (2007), pp. 121-130

BEA, 2005. Local Area Personal Income. http://www.bea.gov/bea/regional/reis/ (retrieved 06.03.06).

BLS, 2005. State and County Employment and Wages from the Quarterly Census of Employment and Wages (2001 forward). Retrieved March 6, 2006 from http://data.bls.gov/PDQ/outside.jsp?survey=en.

J. Bowen, T. Leinbach. Market concentration in the air freight forwarding industry. Tijdschrift voor Economische en Sociale Geografie, 95 (2) (2004), pp. 174-188

Brookings Institution, 2002. Signs of Life: The Growth of Biotechnology Centers in the U.S.

K. Brueckner. Airline traffic and urban economic development. Urban Studies, 40 (2003), pp. 1455-1469

K. Button, S. Lall, R. Stough, M. Trice. High-technology employment and hub airports. Journal of Air Transport Management, 5 (1) (1999), pp. 53-59

K. Button, S. Taylor. International air transportation and economic development. Journal of Air Transport Management, 6 (4) (2000), pp. 209-222

J.P. Cohen, C.J.M. Paul. Airport infrastructure spillovers in a network system. Journal of Urban Economics, 54 (3) (2003), pp. 459-473

K.G. Debbage. Air transportation and urban-economic restructuring: competitive advantage in the US Carolinas. Journal of Air Transport Management, 5 (4) (1999), pp. 211-221

K. Debbage, D. Delk. The geography of air passenger volume and local employment patterns by US metropolitan core area: 1973-1996. Journal of Air Transport Management, 7 (3) (2001), pp. 159-167 
P. Dicken. Global Shift: Mapping the Changing Contours of the World Economy. (5th ed.)The Guilford Press, New York (2007) pp. 411-413

R. Doganis. Flying off Course: The Economics of International Airlines. (2nd ed.)Routledge, New York (1991)

A.R. Feighan. Traffic distribution in low-cost and full-service carrier networks in the US air transportation market. Journal of Air Transport Management, 7 (5) (2001), pp. 265-275

A.R. Goetz. Air passenger transportation and growth in the U.S. urban system, 1950-1987. Growth and Change, 23 (1992), pp. 218-242

A.R. Goetz, C.J. Sutton. The geography of deregulation in the U.S. airline industry. Association of American Geographers, 87 (2) (1997), pp. 238-263

R.K. Green. Airports and economic development. Real Estate Economics, 35 (1) (2007), pp. 91112

Haggerty, A. C., 2004. Commercial Market for Cargo Operations Aviation Systems Architecture. Massachusetts Institute of Technology. http://ocw.mit.edu/NR/rdonlyres/Aeronautics-and-Astronautics/16-886 Spring2004/A090313D52EA-4D4B-B3E0-F139D161C6BE/0/08_cargopra tion1.pdf (retrieved 14.06.05).

M.M. Helms. A structure conduct performance analysis of the expedited small package industry. Transportation Quarterly, 43 (1) (1989), pp. 101-122

M. Hesse. Shipping news: the implications of electronic commerce for logistics and freight transport. Resources Conservation and Recycling, 36 (3) (2002), pp. 211-240

M. Hesse, J.P. Rodrigue. The transport geography of logistics and freight distribution. Journal of Transport Geography, 12 (3) (2004), pp. 171-184

R.L. Ivy, T.J. Fik, E.J. Malecki. Changes in air service connectivity and employment. Environment and Planning A, 27 (1995), pp. 165-179

Kasarda, J.D., 2008. Airport Cities: The Evolution. Aerotropolis. http://www.aerotropolis.com/articles.html (retrieved 25.01.09).

J.D. Kasarda, J.D. Green. Air cargo as an economic development engine: a note on opportunities and constraints. Journal of Air Transport Management, 11 (6) (2005), pp. 459-462

Kay, D., 2004. Air Cargo: Engine for Economic Development. TIACA Times.

T.R. Leinbach. City interactions: the dynamics of passenger and freight flows. S. Hanson, G. Giuliano (Eds.), The Geography of Urban Transportation (3rd ed.), The Guilford Press, New York (2004), pp. 30-58 
T.R. Leinbach, J. Bowen. Air cargo services and the electronics industry in southeast Asia. Journal of Economic Geography, 4 (3) (2004), pp. 299-321

K.J. Mason. Observations of fundamental changes in the demand for aviation services. Journal of Air Transport Management, 11 (1) (2005), pp. 19-25

Milken Institute, 2004. America’s Biotech and Life Science Clusters: San Diego's Position and Economic Contributions.

http://www.milkeninstitute.org/publications/publications.taf?function=detail\&ID=312\&cat=Res Rep (retrieved 29.04.08).

Moline, A., 2004. Understanding logistics and the supply chain process. In: Just in Time Real Estate: How Trends in Logistics are Driving Industrial Development, Washington, D.C.: ULI Urban Land Institute, pp. 7-28.

P. Murphy, D. Dalenberg, J. Daley. Improving international trade efficiency: airport and air cargo concerns. Transportation Journal, 29 (1989), pp. 27-36

K. O’Connor. Global air travel: toward concentration or dispersal. Journal of Transport Geography, 11 (2) (2003), pp. 83-92

W.E. O’Connor. An Introduction to Airline Economics. (6th ed.)Praeger, Westport (2001)

J.C.V. Oster, B.M. Rubin, J.S. Strong. Economic impacts of transportation investments: the case of federal express. Transportation Journal, 37 (2) (1997), pp. 34-44

C.G. Pinkowski. The national lodging market and how Memphis fits "Inn.” Business Perspectives, 19 (1) (2007)

J.P. Rodrigue. Freight, gateways and mega-urban regions: the logistical integration of the Bostwash corridor. Tijdschrift voor Economische en Sociale Geografie, 95 (2) (2004), pp. 147161

Rodrigue, J. P., 2006. The Geography of Transport Systems. Hofstra University. http://people.hofstra.edu/geotrans/eng/ch3en/conc3en/ch3c4en.html (retrieved 03.03.06).

A. Rong, M. Grunow. Shift designs for freight handling personnel at air cargo terminals. Transportation Research Part E: Logistics and Transportation Review, 59 (2) (2010), pp. 334343

E. Taaffe. Air transportation and United States urban distribution. Geographical Review, 46 (2) (1956), pp. 219-238 
U.S. BTS, 2005a. Air Carriers: T-100 Market- Air Freight Definitions.

http://www.transtats.bts.gov/TableInfo.asp?Table_ID=292\&DB_Short_Name=Air\%20Carriers\& Info_Only $=0$ (retrieved 03.03.06).

U.S. BTS, 2005b. Final Rule Changes to T-100 and T-100(f) Traffic Reporting Systems. http://www.bts.gov/programs/airline_information/accounting_and_reporting_directives/number 261.html (retrieved 09.03.06)

U.S. BTS., 2005c. U.S.-North American Trade and Freight Transportation Highlights. http://www.bts.gov/publications/us_north_american_trade_and_freight transportation_highlights L (retrieved 06.04.10).

U.S. BTS, 2005d. Air Carrier Statistics (Form 41 Traffic)-All Carriers: T-100 Market (All Carriers) Table: Sum: On-Flight Market Freight Enplaned (pounds) by Origin, 2003.

U.S. BTS. 2005e. Air Carrier Statistics (Form 41 Traffic)-All Carriers: T-100 Market (All Carriers): On-Flight Market Freight Enplaned (pounds) by Class, 2003.

U.S. BTS, 2005f. Air Carrier Statistics (Form 41 Traffic)-All Carriers: T-100 Market (All Carriers) Table: Tennessee, 2003.

U.S. Census Bureau. 2005. 2005 American Community Survey. <http://factfinder.census.gov/> (retrieved 07.03.06).

U.S. Census Bureau, 2009. About SAIPE. http://www.census.gov//did/www/saipe/about/index.html (retrieved 04.01.09).

U.S. Government Printing Office, 2009. Section 03 Definitions for Purposes of This System of Accounts and Reports - Freight. Electronic Code of Federal Regulations.

T.M. Vowles. Geographic perspectives of air transportation. The Professional Geographer, 58 (1) (2006), pp. 12-19

K. Yamaguchi. International trade and air cargo: analysis of US export and air transport policy. Transportation Research Part E: Logistics and Transportation Review, 44 (4) (2008), pp. 653663

A. Zhang, Y. Zhang. A model of air cargo liberalization: passenger vs. all-cargo carriers. Transportation Research Part E: Logistics and Transportation Review, 38 (3-4) (2002), pp. 175191 